\title{
Retraction Note to: High expression level and nuclear localization of Sam68 are associated with progression and poor prognosis in colorectal cancer
}

\author{
Wen-Ting Liao ${ }^{1,3}$, Jun-Ling Liư ${ }^{4}$, Zheng-Gen Wang ${ }^{5}$, Yan-Mei Cui ${ }^{1,3}$, Ling Shi ${ }^{2}$, Ting-Ting Li ${ }^{1,3}$, Xiao-Hui Zhao ${ }^{2}$,
} Xiu-Ting Chen ${ }^{2}$, Yan-Qing Ding ${ }^{1,3^{*}}$ and Li-Bing Song ${ }^{2^{*}}$

\section{Retraction note to: BMC Gastroenterol 2013, 13:126}

https://doi.org/10.1186/1471-230X-13-126

The Editor has retracted this article after a number of concerns were raised, including:

- Overlapping panels in Figures 2 and 3

- Inaccurate description of Figure 2 parts $\mathrm{A}-\mathrm{C}$ in the figure legend

- Lack of discussion of the difference between the behaviour of the cell line COLO205 compared with the other cell lines used

- Lack of methodological information relating to the 9 paired colorectal cancer tissue samples

- No description of normal cell lines used and inconsistencies in the descriptions of colorectal cell lines

The Editor no longer has confidence in the results and conclusions presented. Yan-Mei $\mathrm{Cu}$ agrees with this retraction. Wen-Ting Liao and Li-Bing Song disagree with this retraction. Jun-Ling Liu, Zheng-Gen Wang,

The original article can be found online at https://doi.org/10.1186/1471-230X13-126.

*Correspondence: dyq@fimmu.com; lb.song1@gmail.com

1 Department of Pathology, Nanfang Hospital, Southern Medical

University, Guangzhou 510515, Guangdong, People's Republic of China

${ }^{2}$ State Key Laboratory of Oncology in Southern China, Department

of Experimental Research, Sun Yat-Sen University Cancer Center,

Guangzhou 510060, Guangdong, People's Republic of China

Full list of author information is available at the end of the article
Ling Shi, Ting-Ting Li, Xiao-Hui Zhao, Xiu-Ting Chen and Yan-Qing Ding have not responded to correspondence from the Editor about this retraction.

\begin{abstract}
Author details
'Department of Pathology, Nanfang Hospital, Southern Medical University, Guangzhou 510515, Guangdong, People's Republic of China. ${ }^{2}$ State Key Laboratory of Oncology in Southern China, Department of Experimental Research, Sun Yat-Sen University Cancer Center, Guangzhou 510060, Guangdong, People's Republic of China. ${ }^{3}$ Department of Pathology, School of Basic Medical Sciences, Southern Medical University, Guangzhou 510515, People's Republic of China. ${ }^{4}$ State Key Laboratory of Oncology in South China, Department of Medical Oncology, Sun Yat-Sen University Cancer Center, Guangzhou 510060, Guangdong, People's Republic of China. ${ }^{5}$ Department of Gastroenterology, The Second Affiliated Hospital, University of South China, HengYang 421000, Hunan, People's Republic of China.
\end{abstract}

Published online: 11 October 2021

\section{Publisher's Note}

Springer Nature remains neutral with regard to jurisdictional claims in published maps and institutional affiliations.

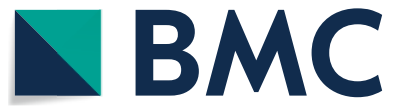

(- The Author(s) 2021. Open Access This article is licensed under a Creative Commons Attribution 4.0 International License, which permits use, sharing, adaptation, distribution and reproduction in any medium or format, as long as you give appropriate credit to the original author(s) and the source, provide a link to the Creative Commons licence, and indicate if changes were made. The images or other third party material in this article are included in the article's Creative Commons licence, unless indicated otherwise in a credit line to the material. If material is not included in the article's Creative Commons licence and your intended use is not permitted by statutory regulation or exceeds the permitted use, you will need to obtain permission directly from the copyright holder. To view a copy of this licence, visit http://creativecommons.org/licenses/by/4.0/. The Creative Commons Public Domain Dedication waiver (http://creativecommons.org/publicdomain/zero/1.0// applies to the data made available in this article, unless otherwise stated in a credit line to the data. 